\title{
River Bank Filtration: Study of Langat River Water and Borehole Water Quality
}

\author{
Nurazim Ibrahim ${ }^{1, a}$, Hamidi Abdul Aziz ${ }^{2, b^{*}}$, and Mohd Suffian Yusoff ${ }^{3, c}$ \\ ${ }^{1}$ School of Civil Engineering, Engineering Campus, Universiti Sains Malaysia, 14300 Nibong \\ Tebal, Penang, Malaysia \\ ${ }^{2,3}$ Solid Waste Management Cluster, Engineering Campus, Universiti Sains Malaysia, 14300 \\ Penang, Malaysia \\ amiza_jnx@yahoo.com, bcehamidi@eng.usm.my, ${ }^{\mathrm{c}}$ suffian@usm.my
}

Keywords: Langat River, borehole water, water quality, river bank filtration

\begin{abstract}
The characteristics of water sources and treatments method are important factors that determine the quality of water distributed to consumers. The quality of Langat River and borehole water were investigated in this study to obtain the baseline water quality for riverbank filtration (RBF) systems. Water samples from Langat River and seven boreholes constructed at different distances from the river bank were collected and analyzed for $\mathrm{pH}$, turbidity, color, TDS, COD, $E$. coli, and heavy metals. Results indicate that the levels of DO, COD, and TDS in the river are 5.56, 53.0 , and $142.9 \mathrm{mg} / \mathrm{L}$, respectively. The water is turbid with a turbidity value of $62.3 \mathrm{NTU}$. Metals in the river water are not an issue, except for iron (Fe) and arsenic (As) with concentration of 1.44 and $0.073 \mathrm{mg} / \mathrm{L}$, respectively. In addition, the concentration of the pathogenic bacteria $E$. coli in the river is also high with a value of 5,000 per $100 \mathrm{~mL}$. The quality of water from boreholes exhibits improvement in terms of turbidity, color, total dissolve solid (TDS), COD, and E. coli. However, the levels of trace elements, such as arsenic (As), iron (Fe) and manganese ( $\mathrm{Mn})$ are higher in boreholes; the readings reached $0.13,14.96$ and $0.95 \mathrm{mg} / \mathrm{L}$ respectively. Based on the information presented, this study may be able to provide baseline information regarding the suitability of an RBF system for a selected area.
\end{abstract}

\section{Introduction}

Generally, surface water and groundwater are exploited for many purposes (e.g., domestic, industrial, and agricultural), including the derivation of drinking water. In Malaysia, river water is one of the major sources that serve these purposes. However, the quality of this water source is degrading along with urbanization [1]. Therefore, continuous assessment of river water, especially river basins, is necessary. The body responsible for monitoring river water quality in Malaysia is the Department of Environmental (DOE). State water authorities are responsible for monitoring water intake by treatment plants. River water quality is measured based on a water quality index (WQI), which is built from six selected parameters, namely, dissolved oxygen (DO), $\mathrm{BOD}_{5}, \mathrm{COD}, \mathrm{SS}$, $\mathrm{NH}_{3}-\mathrm{N}$, and $\mathrm{pH}$. According to the latest Environmental Quality Report issued by Malaysia's DOE, $34 \%$ and $7 \%$ of the 473 rivers monitored are slightly polluted and polluted, respectively. Pollution is mainly caused by human activities, such as agro-based industries, farming, manufacturing industries, livestock, domestic sewage, and earthwork [2]. Langat River in Selangor is an example of a river basin that has a history of river water pollution associated with these activities [3].

For more than 40 years, Langat River has been providing freshwater sources to half of the Selangor population and has served as a source of hydropower and flood control [3]. Langat River is exposed to contamination from anthropogenic activities as a consequence of urbanization. The alteration of land for development purposes, especially along the river basin, has accelerated river deterioration [4]. The study of river water characteristics is essential to determine the extent of contamination [5]. Apart from river water quality, this study also aims to determine the potential of river bank/bed filtration (RBF) as an alternative method of water treatment. RBF is a conventional method that offers a good potential in treating and protecting surface water and groundwater. RBF is commonly utilized as a pretreatment step for drinking water production from polluted river water in Germany according to [6]. The main processes in RBF involved in pollution level reduction are 
dispersion, physical filtration, biodegradation, ion exchange, adsorption, and dilution [6-7]. However, this method depends on the physical characteristics of river water and aquifer layer properties [8]. Thus, this study focuses on reporting Langat River water quality and borehole water quality at the river bank. This information can be utilized as baseline data for an alternative water treatment process that involves a natural filtration process, such as RBF.

\section{Methodology}

Site Description: Langat River is the main tributary to Langat River basin, which originates from Nuang Mountain at Hulu Langat Selangor and receives an average annual rainfall of $2400 \mathrm{~mm}$ [9]. The river basin lies between the latitude $2^{\circ} 40^{\prime} 152^{\prime \prime} \mathrm{N}$ and the longitude $101^{\circ} 19^{\prime} 20^{\prime \prime} \mathrm{E}$ to latitude $3^{\circ} 16^{\prime} 15^{\prime \prime} \mathrm{N}$ and longitude $102^{\circ} 1$ ' $10^{\prime \prime} \mathrm{E}$; it covers approximately $1,815 \mathrm{~km}^{2}$ of catchment area. This study focuses on the lower section of the hilly area (downstream). The selected site is located at the junction of Jenderam Hilir River and Langat River which covers an area of $100 \mathrm{~m} \times 100 \mathrm{~m}$. Near to this area are Orang Asli residences and a palm oil plantation. Seven boreholes consist of one pumping well (PW) and six monitoring wells (MWs) was constructed at different distance for the site investigation study.

Sampling and analysis: A set of samples was collected after a pumping test to analyze the quality of the river and borehole water. Boreholes were purged for 10 min before sampling. All samples for analytical testing were collected in polyethylene bottles, and sterilized reagent bottles were utilized to collect water samples for $E$. coli analysis. The samples were preserved in accordance with water and wastewater standards. In-situ parameters ( $\mathrm{pH}, \mathrm{DO}$, and TDS) were analyzed using YSI Professional Plus Multi-parameter instrument. Turbidity was measured with an HACH Turbidimeter (model 2100 Q) while DR2800 HACH spectrophotometer was employed for color determination. Each water sample was pre-filtered before color measurement with a $0.45 \mu \mathrm{m}$ nylon syringe filter from Whatman. A test to detect the presence of total coliform and E. coli in the water samples was conducted with a Colilert test kit from IDEXX Corporation as soon as the samples arrived at the laboratory. The most probable number (MPN) for E. coli was calculated after $24 \mathrm{~h}$ of incubation at $35^{\circ} \mathrm{C} \pm 5^{\circ} \mathrm{C}$ through the MPN table provided. Close reflux and colorimetric method (5220D) were used to determine the COD concentration. The samples collected for trace metal analysis were filtered and acidified with $\mathrm{HNO}_{3}$ to obtain $\mathrm{pH}$ less than 2 . The trace elements were analyzed with Varian ICP-OES model 715-ES using 21 element stock solutions from Merck, Darmstadt, Germany, as the standard solution.

\section{Results and discussion}

The quality of drinking water typically depends on the quality of the water source and its management. Langat River was selected because it has high probability of water source deterioration given that the river is located at the center of urban cities and easily exposed to pollutants. During the study, $\mathrm{pH}$ value in the river water was 6.37 , which is within the permissible limit stated by $\mathrm{MOH}$ (6.50 to 9.0). According to [3], the $\mathrm{pH}$ of river water is near to neutral because the downstream area of Langat River has high level of exposure to seawater. Thus the $\mathrm{pH}$ value tend to increase. A high amount of TDS in river water is also implies the possibility of sea water intrusion into the river water as mention by $[4,10]$ or the presence of dissolved substances [11]. The possibility of seawater intrusion is realistic because the distance of study site and Malacca Straits is not far with the distance of $40 \mathrm{~km}$ approximately.

However, Langat River showed high concentrations of turbidity and color, with values of 62.3 NTU and 17 PtCo, respectively. Intensive land use along the river has contributed to the increase in the amount of sediments entering the river whilst increased the concentration of turbidity in the water. In addition, dissolved organic carbon (DOC) is carried together with the sediments and causes the color to become yellow [12]. COD in Langat River water is also high and exceeds the $\mathrm{MOH}$ raw water standard $(10 \mathrm{mg} / \mathrm{L})$ with the values of $53.0 \mathrm{mg} / \mathrm{L}$. The high concentration of COD 
indicates that highly oxidizable materials exist in the water. Additionally, E. coli concentration is also high, with values of $5 \times 10^{\wedge} 3 \mathrm{MPN}$ per $100 \mathrm{ml}$ sample. The values are over the maximum concentration permitted by $\mathrm{MOH}$ for drinking water standards. This result indicates that the level of bacteriologic pollution in Langat River is high.

In terms of metal presence, the analysis shows that Langat River has a high concentration of iron (Fe), with an amount of $1.44 \mathrm{mg} / \mathrm{L}$. Arsenic (As) concentration is slightly higher $(0.073 \mathrm{mg} / \mathrm{L})$ than the raw drinking water permissible limit $(0.01 \mathrm{mg} / \mathrm{L})$. The high concentration of Fe in river water indicates that the river is contaminated with anthropogenic sources, such as overland flow and runoff [13]. The manganese $(\mathrm{Mn})$ content in the river barely passed the permissible limit $(0.1 \mathrm{mg} / \mathrm{L})$ by $\mathrm{MOH}$, with concentration of $0.093 \mathrm{mg} / \mathrm{L}$. These results indicate that Langat River is polluted, and its water is unsuitable for direct use as shown in Table 2. Hence, a suitable water treatment system is required to treat the water.

Table 2. Comparison of Langat River and borehole water with the drinking water quality standard set by $\mathrm{MOH}$

\begin{tabular}{|c|c|c|c|c|c|c|c|c|c|c|}
\hline \multirow{2}{*}{$\begin{array}{c}\text { Test } \\
\text { Parameter }\end{array}$} & \multirow[b]{2}{*}{ Unit } & \multicolumn{8}{|c|}{ Results } & \multirow{2}{*}{$\begin{array}{c}\text { Drinking } \\
\text { Water } \\
\text { Quality }\end{array}$} \\
\hline & & $\begin{array}{c}\text { Sg. } \\
\text { Langat }\end{array}$ & $\begin{array}{c}\text { MW } \\
\text { 01 }\end{array}$ & $\begin{array}{c}\text { MW } \\
\text { 02 }\end{array}$ & $\begin{array}{c}\text { MW } \\
\mathbf{0 3}\end{array}$ & $\begin{array}{c}\text { MW } \\
04\end{array}$ & $\begin{array}{c}\text { MW } \\
05\end{array}$ & $\begin{array}{c}\text { MW } \\
06\end{array}$ & PW & \\
\hline $\mathrm{pH}$ & - & 6.37 & 5.75 & 5.74 & 5.93 & 5.43 & 5.53 & 5.58 & 5.32 & $6.5-9.0$ \\
\hline True Colour & $\mathrm{PtCo}$ & 17 & 5 & 7 & 13 & 6 & 5 & 15 & 7 & 15 \\
\hline Turbidity & NTU & 62.3 & 2.84 & 9.02 & 119 & 0.24 & 1.66 & 0.88 & 0.27 & 5 \\
\hline DO & $\mathrm{mg} / \mathrm{L}$ & 5.56 & 2.96 & 2.38 & 2.99 & 2.36 & 2.39 & 2.43 & 1.94 & - \\
\hline TDS & $\mathrm{mg} / \mathrm{L}$ & 142.9 & 46.8 & 52.7 & 109 & 50.6 & 60.6 & 126.3 & 70.0 & 1000 \\
\hline $\mathrm{COD}$ & $\mathrm{mg} / \mathrm{L}$ & 53 & 8 & ND & ND & ND & ND & 18 & ND & - \\
\hline E.Coli & $\begin{array}{l}\mathrm{MPN} / \\
100 \mathrm{ml}\end{array}$ & $5 \times 10^{\wedge} 3$ & ND & ND & 2 & ND & ND & 1 & ND & ABSENT \\
\hline \multicolumn{11}{|l|}{ Heavy Metal } \\
\hline Arsenic as As & $\mathrm{mg} / \mathrm{L}$ & 0.073 & ND & 0.064 & ND & ND & 0.126 & 0.108 & 0.086 & 0.01 \\
\hline Iron as $\mathrm{Fe}$ & $\mathrm{mg} / \mathrm{L}$ & 1.440 & 5.395 & 6.505 & 12.36 & 5.495 & 6.097 & 14.96 & 8.809 & 0.3 \\
\hline $\begin{array}{l}\text { Manganese as } \\
\text { Mn }\end{array}$ & $\mathrm{mg} / \mathrm{L}$ & 0.093 & 0.945 & 1.474 & 1.135 & 0.676 & 0.950 & 0.924 & 0.348 & 0.1 \\
\hline
\end{tabular}

The $\mathrm{pH}$ value in the boreholes is more acidic compared to river water, with $\mathrm{pH}$ ranging from 5.3 to 5.9. Considering that the values are outside the drinking water standard, the water can be considered low-quality drinking water [11]. Table 2 shows that the physico-chemical characteristics of the river water improved through the RBF process. The concentrations of turbidity, color, TDS, COD and E.coli in borehole water were significantly reduced. Turbidity was reduced from 62.3 NTU to less than $5 \mathrm{NTU}$ as required by MOH guidelines for drinking water, except for MW02 and MW03. This phenomenon is understandable because the water was naturally filtered during the RBF process. The reduction in these parameters was influenced by aerobic, anoxic, and anaerobic processes in groundwater as explained by [14].

The improvement in water quality was not dependent on the distance of the river to the boreholes. Other factors, such as site geology, biogeochemical processes, and land use, probably contributed to the decrease in pollutant concentrations in this case [15]. The combination of several processes and interactions within the aquifer during filtration determines the quality of borehole water. Meanwhile, TDS in the boreholes was determined according to the types of minerals in the aquifer and time contact of water with the minerals [16].

Similar trace elements were discovered in the borehole water. The concentration of As in MW05, MW06, and PW were higher than that in the river water. The presence of As is a concern because this trace metal is known to have adverse effects on human health [17]. The maximum permissible limit of this element in drinking water is $0.01 \mathrm{mg} / \mathrm{L}$. However, the concentration value 
obtained from the analysis exceeds the standard, as shown in Table 2. The study conducted by [18] showed that high As concentration is generally influenced by low $\mathrm{pH}(<6.5)$ and redox potential. Thus, the acidic condition (5.32 to 5.93) in this study may enhance the release of As from sediment to water. In addition, the release of As in groundwater is also related to the ions exchanged between Fe oxides and As under anaerobic conditions. This condition usually occurs in young-deposited, fine-grained deltaic and alluvial sediments.

Fe provides color and odor to water when the concentration is higher than the maximum permissible limit $(0.3 \mathrm{mg} / \mathrm{L})$ [18]. Fe intoxication may also occur among a number of people with genetic and metabolic diseases, such as hemachromatosis [19]. Table 2 shows that Fe concentrations in both river and borehole water exceed the stated limit. Fe detected in river water was $1.4 \mathrm{mg} / \mathrm{L}$, whereas $\mathrm{Fe}$ in the boreholes ranged between 5.395 and $14.955 \mathrm{mg} / \mathrm{L}$. This is possible because $\mathrm{Fe}$ is one of the most abundant elements in the Earth's crust and easily weathered. Besides that, [16] also suggested that water will have a high concentration of Fe during reduction condition if the local environment produces iron oxide $(\mathrm{FeO})$ or iron hydroxide $(\mathrm{Fe}[\mathrm{OH}])$. Thus, the increase in Fe concentration in borehole water may be related to the geochemical condition and ions exchanged in the aquifer during filtration.

$\mathrm{Mn}$ is a good nutrient and not a hazard to humans within a certain concentration. However, it becomes hazardous to living organisms and humans when the concentration is higher than the maximum permissible limit. Mn poisoning may lead to hallucinations, forgetfulness, and nerve damage [16]. Mn detected in the river water was $0.068 \mathrm{mg} / \mathrm{L}$, which nearly exceeds the permissible limit of $0.1 \mathrm{mg} / \mathrm{L}$. Furthermore, the Mn content in all the boreholes is higher than that in river water, with concentrations of more than $0.3 \mathrm{mg} / \mathrm{L}$, which is over the stated limit. Lee [13] suggested that the high concentration of $\mathrm{Mn}$ in borehole water is possibly caused by the reduced environment of the alluvium.

\section{Conclusions}

This study highlighted the importance of river water physico-chemical characteristics in determining the quality of river water as a drinking water source. The results indicate that Langat River water is unsuitable for drinking without proper treatment. The concentrations of turbidity, colour and E. coli were higher than set standards, with values of $62.3 \mathrm{NTU}, 17 \mathrm{PtCo}$ and $5 \times 10^{\wedge} 3$ MPN/100 ml, respectively. The results also revealed differences in river and borehole water quality. The RBF system provided a good treatment for turbidity, color, COD, TDS, and E. coli during the study period by reducing the amount of pollutants to meet the drinking water quality standard set by $\mathrm{MOH}$, Malaysia. However, a disadvantage of this treatment is the increased of heavy metal concentration. Several metals, such as As, Fe, and Mn, exceeded the permissible limit stated by the set standard. The detected As, Fe, and Mn concentrations reached 0.13, 14.96, and $1.47 \mathrm{mg} / \mathrm{L}$, respectively. Therefore the information obtained from this study can be used as a reference in determining the suitability of an RBF system for a selected area. Additionally, this data can be used as a guide to propose a suitable and cost effective treatment process (e.g. aeration and adsorption by low cost media) for removing metal in production well.

\section{Acknowledgement}

The authors wish to acknowledge Ministry of Higher Education, Malaysia for supporting this study by providing Large Research Grant Scheme (LRGS) (Grant no. 203/PKT/6726001) for research related to Protection of Drinking Water for Society: Source Abstraction and Treatment and supporting the current $\mathrm{PhD}$ student through MyBrain15 Scholarship. 


\section{References}

[1] Fulazzaky, M. A., T. W. Seong, and M. I. M. Masirin. Assessment of water quality status for the Selangor River in Malaysia. Water, Air, \& Soil Pollution. 205, no. 1 (2010) 63-77.

[2] Information on http://www.doe.gov.my/library/laporan-tahunanperpustakaan/?browse=Laporan+Tahunan. Department of Environmental (DOE) Malaysia. Malaysia Environmental Quality Report 2012. Online on 21 July 2014.

[3] Juahir, Hafizan, Sharifuddin M. Zain, Mohd Kamil Yusoff, TI Tengku Hanidza, AS Mohd Armi, Mohd Ekhwan Toriman, and Mazlin Mokhtar. "Spatial water quality assessment of Langat River Basin (Malaysia) using environmetric techniques." Environmental monitoring and assessment 173, no. 1-4 (2011) 625-641.

[4] Lim, W. Y., Aris, A. Z., Ismail, T. H. T., \& Zakaria, M. P. Elemental hydrochemistry assessment on its variation and quality status in Langat River, Western Peninsular Malaysia. Environmental Earth Sciences, 70 no. 3, (2013) 993-1004.

[5] Lim, W. Y., Aris, A. Z., \& Tengku Ismail, T. H. "Spatial Geochemical Distribution and Sources of Heavy Metals in the Sediment of Langat River, Western Peninsular Malaysia." Environmental Forensics 14 no. 2, (2013) 133-145.

[6] Worch, E., T. Grischek, H. BÃ $\lceil$ rnick, and P. Eppinger. Laboratory tests for simulating attenuation processes of aromatic amines in riverbank filtration. Journal of Hydrology 266 no. 3, (2002), 259-268.

[7] Jaramillo, Marcela. "Riverbank filtration: an efficient and economical drinking-water treatment technology." Dyna 171 (2012), 148-157.

[8] Kuehn, W., and U. Mueller. 2000. Riverbank filtration: an overview. Journal American Water Works Association 92 no. 12 (2000), 60-69.

[9] Memarian, Hadi, Siva K. Balasundram, Jamal B. Talib, Alias M. Sood, and Karim C. Abbaspour. "Trend analysis of water discharge and sediment load during the past three decades of development in the Langat basin, Malaysia." Hydrological Sciences Journal 57, no. 6 (2012): 12071222.

[10] Aris, A. Z., Abdullah, M. H., Kim, K. W., and Praveena, S. M. Hydrochemical changes in a small tropical island's aquifer: Manukan Island, Sabah, Malaysia. Environmental Geology, 56 no. 8, (2009), 1721-1732.

[11] Efe, S. I., Ogban, F. E., Horsfall, M. J., and Akporhonor, E. E. (2005). Seasonal variations of physico-chemical characteristics in water resources quality in western Niger Delta region, Nigeria. J. Appl. Sci. Environ. Mgt. Vol. 9 no. 1, (2005), 191 - 195

[12] Matilainen, A., and Sillanpää, M. Removal of natural organic matter from drinking water by advanced oxidation processes. Chemosphere 80 no. 4, (2010), 351-365.

[13] Lee J.H, Hamm S.Y, Cheong J.Y, Kim H.S, Ko E.J, Lee K.S, Lee S.I Characterizing riverbank-filtered water and river water qualities at a site in the lower Nakdong River basin, Republic of Korea. Journal of Hydrology, 376 no. 1, (2009), 209-220.

[14] Essandoh, H. M. K., Tizaoui, C., Mohamed, M. H. A., Amy, G., and Brdjanovic, D. Soil aquifer treatment of artificial wastewater under saturated conditions. Water research, 45 no. 14, (2011), 4211-4226.

[15] Hudson, N., Andy B., and Darren R. Fluorescence analysis of dissolved organic matter in natural, waste and polluted waters: a review. River Research and Applications 23 no. 6, (2007), 631-649.

[16] Nelson, D. Natural variations in the composition of groundwater. In Presented at Groundwater Foundation Annual Meeting. (2002)

[17] Rahman, M. M., Naidu, R., and Bhattacharya, P. Arsenic contamination in groundwater in the Southeast Asia region. Environmental geochemistry and health, 31 no.1, (2009), 9-21.

[18] Chanpiwat, P., Sthiannopkao, S., Cho, K. H., Kim, K. W., San, V., Suvanthong, B., and Vongthavady, C. Contamination by arsenic and other trace elements of tube-well water along the Mekong River in Lao PDR. Environmental Pollution, 159 no. 2, (2011) 567-576.

[19] Postawa, A., \& Hayes, C. Best Practice Guide on the Control of Iron and Manganese in Water Supply. IWA Publishing. (2013) 